\title{
118. 真空断熱層による冷陰極蛍光ランプの低消費電力化
}

\author{
西村 潔 筒井直樹 \\ （東芝ライテック株式会社）
}

\section{1. はじめに}

携帯情報機器の普及に従い、冷陰極蛍光ランプの低消費電力化が課題となつている。一般に、冷陰極蛍光ランプの 発光効率は水銀蒸気圧に依存する。しか心、消費電力を低下させるとランプ温度が上昇せず、適切な水銀蒸気圧が得 られなくなる。そこで、ランプ外面に真空断熱層を設けてランプの放熱量をコントロールすることで、低消費電力でありな がら高効率の冷陰極蛍光ランプを開発したので報告する。

\section{2. 開発ランプの構造と真空断熱の原理}

本ランプの構造を図1に示す。発光管の周囲に 100〜200 $\mu \mathrm{m}$ の間 隔で外管を設けて、真空断熱層を形成した。

気体分子の平均自由工程 $\lambda$ が断熱層の間隔dより大きくなる分子流域 においては、熱の交換は壁面と表面の気体分子の間で直接行われる ため、内部の気体分子の速度に温度勾配は生じない。 平行壁における熱流の流れは次式で示される。

$$
q=\Lambda p\left(T_{1}-T_{2}\right)
$$

ここで、 $\mathrm{T}_{1}, \mathrm{~T}_{2}$ は内壁、外壁の温度、pは気体の圧力、 $\Lambda$ は自由分子熱 伝導率と呼ばれ以下の式で示される。

$$
\Lambda=\frac{1}{2}\left(\frac{\gamma+1}{\gamma-1}\right) \sqrt{\frac{R}{2 \pi M}} \frac{2}{\sqrt{T_{1}}+\sqrt{T_{2}}}
$$

ここで、Mは気体の分子量、Rは気体定数、 $\gamma$ は定圧比熱 $\mathrm{C}_{\mathrm{p}}$ と定容比 熱 $\mathrm{C}_{\mathrm{v}}$ の比 $\left(\mathrm{C}_{\mathrm{p}} / \mathrm{C}_{\mathrm{v}}\right)$ 、である。分子流域において熱流量qは壁面の 温度差 $\mathrm{T}_{2}-\mathrm{T}_{1}$ と圧力 $\mathrm{p}$ に比例儿、壁面の間隔によらない。

\section{3. 実话桔果}

実験に用いた発光管の外径は $\phi 1.6 \sim 2.2 \mathrm{~mm}$ 、外管の外径は $\phi 2.2 \sim 3.0 \mathrm{~mm}_{\text {。 }}$ 発光管と外管の片端部を封止し、ソープションポン プおよびイオンポンプにて構成した排気装置に接続した。外管に封 入する $\mathrm{N}_{2}$ の圧力を変化させながら輝度計(TOPCON 社 BM-7)にて ランプ輝度を測定した。図2に $\mathrm{N}_{2}$ 圧とランプ輝度の関係を示す。消費 電力が小であるほど最適ガス圧が低下し、1.0W 以下では1Pa 以下、 $1.5 \mathrm{~W}$ では $5 \mathrm{~Pa}$ 付近で最大輝度が得られた。図3は消費電力に対す る発光効率の変化を示す。比較用ランプ(外管なし)は2W 以下では 効率が半分まで低下するが、本ランプはわずかな発熱で発光管温度 を適正值に上昇させることで、大電力時と同等以上の効率が得られ ることが分る。

\section{4. 結詥}

断熱層を設けた冷陰極䖺光ランプの断熱層の圧力依存性と輝度 特性について述べた。本ランプはモバイル機器用バックライトとして

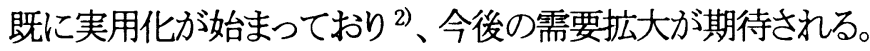

\section{5. 参考文献}

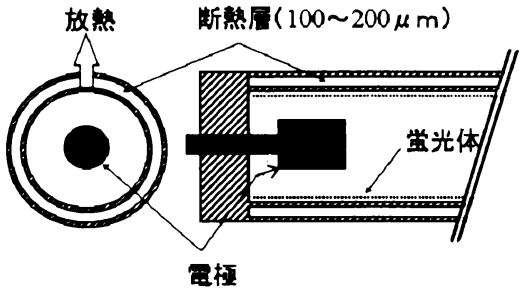

図1 ランプ断面図

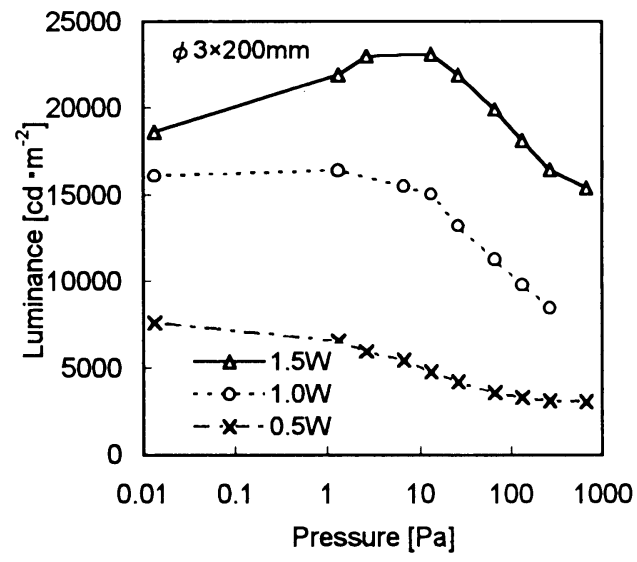

図2 $\mathrm{N}_{2}$ 圧とランプ輝度の関係

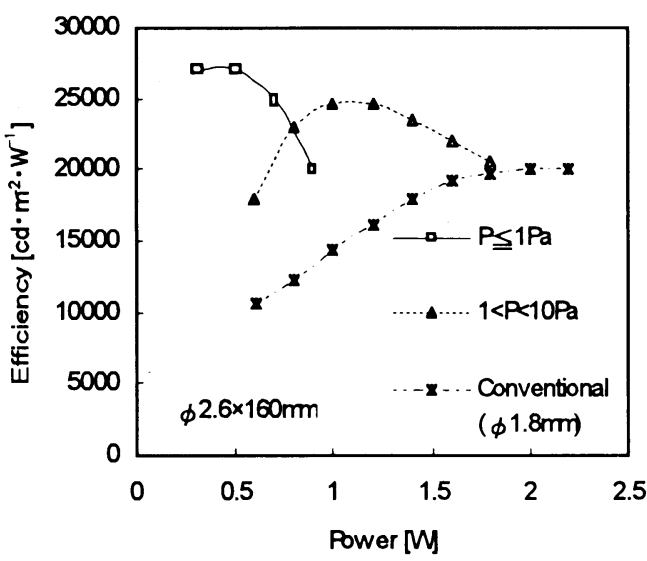

図3 消費電力と発光効率の関係

1)熊谷ら:“真空の物理と応用”、裳華房、1970

2)西村、筒井: “マルチメディア携帯情報機器用蛍光ランプ”、月間ディスプレイ1月号、1997、p85-87

A novel cold cathode fluorescent lamp with an adiabatic layer, Kiyoshi Nishimura, Naoki Tsutsui 